\title{
Explaining electoral fraud in an advanced democracy: fraud vulnerabilities, opportunities and facilitating mechanisms in British elections
}

Dol:

10.1177/1369148117715222

\section{Document Version}

Accepted author manuscript

Link to publication record in Manchester Research Explorer

Citation for published version (APA):

Hill, E., Sobolewska, M., Heeg, S. W., \& Borkowska, M. (2017). Explaining electoral fraud in an advanced democracy: fraud vulnerabilities, opportunities and facilitating mechanisms in British elections. British Journal of Politics and International Relations. https://doi.org/10.1177/1369148117715222

\section{Published in:}

British Journal of Politics and International Relations

\section{Citing this paper}

Please note that where the full-text provided on Manchester Research Explorer is the Author Accepted Manuscript or Proof version this may differ from the final Published version. If citing, it is advised that you check and use the publisher's definitive version.

\section{General rights}

Copyright and moral rights for the publications made accessible in the Research Explorer are retained by the authors and/or other copyright owners and it is a condition of accessing publications that users recognise and abide by the legal requirements associated with these rights.

\section{Takedown policy}

If you believe that this document breaches copyright please refer to the University of Manchester's Takedown Procedures [http://man.ac.uk/04Y6Bo] or contact uml.scholarlycommunications@manchester.ac.uk providing relevant details, so we can investigate your claim.

\section{OPEN ACCESS}




\title{
Explaining electoral fraud in an advanced democracy: fraud vulnerabilities,
} opportunities and facilitating mechanisms in British elections

\author{
Eleanor Hill ${ }^{1}$, Maria Sobolewska², Stuart Wilks-Heeg ${ }^{3}$ and Magda Borkowska4. \\ ${ }^{I}$ Department of Politics, University of Manchester, UK; ${ }^{2}$ Department of Politics and Centre on \\ Dynamics of Ethnicity, University of Manchester, UK; ${ }^{3}$ Department of Politics, University of \\ Liverpool, UK; ${ }^{4}$ Cathie Marsh Institute for Social Research, University of Manchester, UK
}

British Journal of Politics and International Relations, Forthcoming.

\section{Acknowledgements}

First of all, we thank the Electoral Commission who originally commissioned the interview data presented in this article. We would also like to thank the anonymous reviewers and the BJPIR editorial team for their helpful comments on this article. $\mathrm{Dr}$ Toby James read an earlier version of this paper and we thank him for his invaluable feedback. Versions of this paper were presented at the Political Studies Association conference and the Elections, Public Opinion and Parties conference. We thank the discussants and attendees for their comments. Eleanor Hill would also like to acknowledge the grant support of the Economic and Social Research Council, Grant Number: ES/J500094/1.

\section{Disclaimer}

This paper presents the results of independent academic research that do not represent the official position of the Electoral Commission. 
Abstract: Explanatory theories of electoral fraud are usually developed for new and failing democracies. However, while rarer, electoral fraud does happen in advanced democracies. Because data on fraud in advanced democracies are scarce, single instances of fraud are studied in isolation and offer very little generalisability. This study uses a unique comparative dataset of 35 in-depth, semi-structured interviews from eight locations, only half of which experienced allegations of fraud. We show that theories of why and how fraud happens in developing democracies can be extended to an advanced democracy. We also provide a detailed description of two micro-mechanisms, which facilitate fraud taking place and thus provide a causal link between the structural vulnerability to fraud and the direct opportunities for fraud to take place. The case study of Britain focuses mostly on the biraderi structures within the British South Asian communities, but we offer ways in which these generalise more broadly.

\section{Key Words: Electoral fraud, biraderi, political parties, electoral campaigning}

While allegations and instances of electoral fraud in UK elections have received growing attention in recent years, they continue to be rare (Clark and James 2017). This is the case in many developed democracies and is why the majority of the literature focuses on new and failing democracies. Some even identify presence of 
electoral fraud as a distinguishing feature of undemocratic elections (Alvarez, Hall and Hyde, 2008). However, although uncommon, electoral fraud can happen in developed democracies, and our aim is to extend the theoretical framework derived from new and failing democracies to analyse risks of fraud in developed democracies.

Studies into electoral fraud can be divided into three types. The first concentrates on detecting electoral fraud (for example: Hyde 2008; Mebane 2008; Leemannn and Bochsler 2014; Beber and Scacco 2012). The second focuses on the methods used to commit electoral fraud and the reasons why electoral fraud is committed (for example: Lehoucq 2003; Stokes 2005; Stokes et al. 2013; Nichter 2008; Holland and PalmerRubin 2015). Third, advances in voting practices have led to studies focusing on the risks posed by postal and internet voting (Birch and Watt 2004; James, 2011; Alvarez and Hall 2008), and public perceptions of these systems (Saglie and Segaard 2016; Beaulieu 2016; Alvarez and Hall 2008). We contribute to this literature by marrying the different elements of these types of studies. Firstly, we explore how and why electoral fraud occurs focusing on the example of Great Britain, and specifically areas of high concentration of Pakistani and Bangladeshi origin residents, which tend to be associated with fraud (Electoral Commission 2014). However, we use a research design used in quantitative studies seeking to develop ways of detecting electoral fraud (Leemann and Bochsler 2014; Beber and Scacco 2012; Mebane 2006) by 
studying causes of fraud not only in areas where it was detected, but also in areas where it was not. To our knowledge, our application of this approach to a qualitative study seeking to understand electoral fraud occurs is unique. Finally, given the role that postal voting on demand plays in Britain, we draw on and contribute to this literature as well.

Based on the literature, we identify three types of causes of electoral fraud prevalent in developing democracies and show that this typology extends to Great Britain- an advanced democracy. Based on analysis of 35 in-depth interviews with activists from eight wards in England, we argue that each of these causes has a different functional relationship to fraud and each is connected in a chain of causality. The first element in this causal chain is the vulnerabilities to fraud: these are the political system and the socio-economic structural inequalities that create underlying conditions and motives for fraudulent activities. The next element is the opportunities for fraud: how electoral fraud can be committed given the current voting safeguards, including the role of postal voting on demand. Finally, at the end of the causal chain, are the facilitating micro-mechanisms: the link between the conditions ripe for fraud and fraud being committed. We discuss the role of South Asian biraderi networks and political party campaigning in facilitating fraud. 


\section{Existing literature}

The literature on electoral fraud is relatively sparse. Despite new efforts to study this issue in a more systematic way (for example: Norris, Frank and Martínez i Coma 2014; Norris 2015), empirical studies of fraud in developed democracies are usually incidental. In the main, they remain single case studies, are generally descriptive and often focus on how widespread fraud is (Fukimoto and Horichini 2011; Minnite 2010). However, in recent years literature has emerged pinpointing concerns about failings in electoral administration in established democracies and the risks arising for the vulnerability of elections to fraud or error (Norris, Frank and Martínez i Coma 2014; Norris 2015, but see Clark and James 2017 for evidence of low incidence in the UK).

The UK literature focuses on the pressures which the growing frequency and complexity of electoral events have imposed on the electoral system and administration (Wilks-Heeg 2009; James 2013; Clark 2015, 2016). A high volume of legislative changes has imposed burdens on electoral administrators required first to liberalise procedures and then to effectively 'retro-fit' measures to tackle vulnerabilities (Wilks-Heeg 2009; Clark 2015). Eric Pickles recently made recommendations for the introduction of voter ID at polling stations and the requirement for electors to submit new postal vote applications every three years 
(Pickles 2016). The government's response indicates these recommendations will be enacted or are being considered (Cabinet Office, 2016). However, many of these recommendations may be an over-reaction to the actual levels of fraud risk that we present here and that others have analysed elsewhere (Clark and James 2017).

The relative dearth of British literature on electoral fraud can, to an extent, be explained by the infrequency of electoral fraud. Electoral fraud is not widespread, just over 1000 cases of fraud were reported to English police forces from 2008-13, and 20 have resulted in convictions (Electoral Commission 2013). Most involved single wards in local elections, which given the thousands of ward-level elections held annually (2,364 wards were contested in 2013 and 4,500 in the 2014) amount to a tiny number overall (Electoral Commission 2014). However, even this small number may raise worry that fraud occurs at all, in what is one of the world's longest established democracies.

The majority of the literature focuses on how fraud has been committed. For instance, postal voting is commonly believed to undermine the secrecy of the ballot (Birch and Watt 2004, Council of Europe 2007; Wilks-Heeg 2008) and to increase the risk of large-scale fraud (Wilks-Heeg 2008). Despite the concerns expressed by Pickles 
(2016) that voting at polling stations is vulnerable to fraud, Clark and James (2017) find that attempted personation at polling stations is exceptionally rare.

Causal explanations for electoral fraud in the UK are less developed. Party strategies, including pressing for the use of postal votes, have been suggested (Stewart 2006). Also implicated have been biraderi kinship networks, characteristic of British South Asian communities (Wilks-Heeg, 2008; Akhtar 2013; Peace and Akhtar 2015). These networks, led by male elders, provide welfare for their members and were imported through migration from Pakistan and Bangladesh to the UK (Akhtar 2013). This migration is on-going (Charsley et al 2012), and biraderis continue to be important in Britain's Pakistani and Bangladeshi communities. This explanation is potentially farreaching, as all but one of the 18 local authority areas ${ }^{\mathrm{i}}$ at particular risk of electoral fraud identified by the Electoral Commission have sizeable Pakistani or Bangladeshi communities (Electoral Commission 2014). However, locating explanations of fraud so directly within these communities raises allegations of racism (Mawrey 2015) and therefore it is crucial to consider evidence on alternative possibilities. Language barriers have also been suggested: in communities where English is the second language, complex postal voting forms make it easier for ballots to be filled out by someone other than the voter (Metropolitan Police 2006). However, little systematic thinking about the relationship between these causes is evident. 
In the search for more fruitful causal explanations of fraud, we turn to literature from other countries and time periods. Lehoucq's (2003) overview of historical literature from the Americas, Europe and Asia, concludes that socio-economic and political inequality has been associated with electoral fraud. He argues that whilst fraud increases with social inequality, it is the political competition that institutions help to shape that determines the strategies used by parties to rig elections. Particularly, majoritarian systems- used for national elections and many local contests in the UK create more vulnerability to fraud. Lehoucq thus distinguishes between inequality that creates a context ripe for electoral fraud, and the strategies and practices of electoral parties that facilitate fraudulent behaviour. Although Lehoucq does not formalise this distinction, he does observe their different functionality towards electoral fraud. In this paper we will extend this distinction based on functionality.

Similar distinctions between conditions that create vulnerability to fraud and direct mechanisms that facilitate fraudulent action are implicitly made in the research conducted in developing and failing democracies. This literature identifies a number of micro-mechanisms used to commit fraud. Firstly, vote buying, where rewards are offered to voters to induce them to vote for a particular candidate (Stokes 2005). Postal voting potentially enables vote buying in the UK because, without the 
safeguard of the secret ballot, it is possible to monitor targeted voters and ensure that they vote as instructed. Secondly, turnout buying, where rewards are offered to voters to induce them to vote, or not vote, depending on their political affiliations (Nichter 2008). Thirdly, the operation of political brokers carrying out vote and turnout buying (Holland and Palmer-Rubin 2015). Holland and Palmer-Rubin (2015) distinguish between 'party brokers', 'organizational brokers', 'independent brokers' and 'hybrid brokers'; all with a different relationship with and loyalty to political parties and community organisations between which they broker deals. Brokers develop a clientelist relationship with those they target, offering patronage in the form of jobs, goods or money in exchange for political support, leading to what is often referred to as 'patronage politics' (Weingrod 1968). Vote buying and turnout buying are generally understood to be carried out by 'political machines' or 'clientelist parties' (Gans-Morse, Mazzuca and Nitcher 2014).

This literature offers an explicit causal link between structural inequalities that create vulnerability to fraud, and the operation of these political mechanisms that deliver it (although the distinction between socio-economic inequality and poverty is unclear in this literature). According to Stokes (2005), political machines in Argentina targeted poorer members of society who were likely to put a higher value on the rewards offered in exchange for their votes. Jensen and Justesen (2014) found links between 
vote buying and poverty in Africa. Ziblatt (2009) shows the causal impact of landholding inequality on historical patterns of electoral fraud in Germany.

In the discussion of our results we formalise this distinction between vulnerability to fraud such as inequality (although we depart from the strictly socio-economic one and consider other sources of structural exclusion), opportunities for fraud such as lack of ballot secrecy, and mechanisms facilitating fraud such as political brokerage and political machines. We believe this is a major insight to bring into the research on electoral fraud and specifically one that can elucidate why British South Asian communities have a strong association with instances of fraud. Firstly, based on the broad consensus that inequality can create a context vulnerable to electoral fraud, areas with high percentages of Pakistani and Bangladeshi voters may be more vulnerable to electoral fraud due to the structural disadvantages they experience. Moreover, racial discrimination may generate the need for alternative forms of engagement with the electoral process (Lehoucq 2003) and thus the motive for committing fraud. On top of these ethnic inequalities and exclusions, some group members may experience additional inequalities that create more vulnerability to electoral fraud, particularly women. Research has shown that women of Pakistani and Bangladeshi origin are more likely to have their registration forms filled in by someone else (Sobolewska and Heath 2014). This may suggest that men take the lead 
on public life and this could include voting on behalf of their wives or daughters, which could lead to postal voting fraud, personation or undue influence.

Secondly, focusing on the role of political competition and political brokers (Holland and Palmer-Rubin 2015), we can also see parallels with the voters of South Asian origin. There has been some research, and many allegations, that biraderi networks have both enabled fraud by coercing some members and covered up fraud by intimidating potential witnesses (Wilks-Heeg 2008; Akhtar 2013). Some research implicates the role that political parties play in enabling this form of brokerage (Garbaye 2005; Peace and Akhtar 2015). We will construct more explicit theoretical links between these two elements, as well as between the third one: opportunity to commit fraud, which is the most studied, but most weakly theorised in the current literature. In conclusion we discuss the generalisability of our findings and particularly the typology of causes of fraud that we introduce. We also reflect on the policy impact of our research and argue that current efforts to increase security of voting are an over-reaction given the low incidence involved, but also that they are often misdirected as they do not tackle the main areas of the explanatory framework we provide. 


\section{Methodology}

Lehoucq (2003) points to the crucial methodological problem in the fraud literature: selection on the dependent variable. Studying cases of fraud in isolation risks generating conclusions that will either make areas of fraud appear unique, without appreciating similarities they share with other places, or will miss potential crucial differences between areas where fraud has and has not occurred. To avoid this pitfall, we compare areas that had experienced allegations and convictions of electoral fraud with otherwise similar areas that had not, copying the design usually used in quantitative studies on detection (for example Mebane 2008; Leemannn and Bochsler 2014; Beber and Scacco 2012).

We selected eight wards in England ${ }^{\mathrm{ii}}$ : four wards from the vulnerable 'high risk' local authorities identified by the Electoral Commission (2014), (areas with on-going electoral fraud investigations were excluded); and four wards chosen as comparators based on their demographic and political profile. The Electoral Commission identified the 'high risk' areas based on their analysis of allegations of electoral offences, and the outcomes of any subsequent investigations, recorded by UK police forces after 2008. From 2008-13, 62 cases involving allegations of electoral offences were recorded in these areas. While no further action was taken in the majority of these cases, the four local authorities containing the 'high risk' wards have seen at least 18 
people convicted of electoral fraud since 2000 and all 'high risk' wards had been subject to recent electoral fraud allegations. The local authorities where the four comparator wards are located had no convictions and only seven cases of allegations of electoral fraud between 2008-13. These wards were therefore assumed to be 'low risk' areas. All of these wards had local elections in May 2014, two months prior to the start of data collection. All areas contained a significant Pakistani and/or Bangladeshi population: ranging from 27 per cent to over 60 per cent of residents. They also had above average rates of deprivation, according to the 2011 Census. Because of the lack of variance on levels of deprivation in our sample, we are unable to properly examine the role of this factor- as identified by existing literature- and therefore focus more on other sources of structural inequality such as racial exclusion.

Given the current pattern of local election results in urban and metropolitan areas, where the Labour Party dominates, ensuring a political balance of cases proved difficult and there is a bias towards current Labour Party control in the wards studied. Nonetheless, the selection of wards did allow for some variance with respect to past and current levels of party competition, turnout and marginality. 
In total 35 interviews ${ }^{\mathrm{iii}}$ were conducted with people engaged in local politics and community organisations ranging from mosque council leaders, leaders of community and religious organisations, local councillors and candidates, to one MP and one electoral official. 11 of these interviewees were white and 24 were Asian or British Asian, 22 identifying themselves as Pakistani or Bangladeshi. Purposive sampling, with elements of snowballing, was used and the researchers conducted an in-depth scoping exercise, carrying out preliminary conversations with potential gatekeepers and interviewees before conducting full interviews. Interviews were semi-structured and questions were asked relating to four themes: local organisational density and structure, political parties locally, integrity of elections and local electoral context.

To protect the anonymity of interviewees, we only refer to them as 'white' or 'Asian' activists. We aimed to interview five activists per area; however, in some areas unwillingness to take part in the research, and a lack of a well-developed network of activists, made this impossible. This was especially problematic in one of our 'low risk' areas, where we only managed to conduct one interview. However, with the same themes arising in all interviews fairly early on, we felt that without extending our sample, additional interviews in our selected locations were unlikely to yield new evidence. There is a gender imbalance amongst the interviewees; six of 35 interviewees were female activists and two were Pakistani or Bangladeshi female 
activists. This reflects the lack of ethnic and gender diversity of local politicians (Thrasher et al. 2013). Our findings relate mostly to electoral fraud in local elections because our interviewees were local activists, and our interviews took place shortly after local elections. However, our interviewees spoke in general terms, indicating that some of the patterns found here could be applied to all elections.

\section{Discussion of findings}

Based on the existing literature on developing democracies, we identified the three elements of the casual chain of electoral fraud, each with a different functional relationship to fraud. We found that all of them were identified by our respondents as more or less present in their political context. The distribution of these across interviews varies (see Table 1), indicating that their salience is not equal. The first element, the vulnerabilities to electoral fraud, has been largely neglected by UK

electoral fraud literature, but was mentioned by 32 interviewees. Overall, about 14 per cent of all mentions analysed in the interviews related to vulnerabilities. The second element, opportunities for fraud, has been the focus of the literature published about electoral fraud in the UK and indeed was acknowledged by 27 interviewees, although it is clear that in their narratives this is the less significant element (13 per cent of all classified mentions). The final type, the facilitating micro-mechanisms that lead to 
fraud taking place, is often neglected by British literature, but is covered extensively by literature from other countries. We find that this was the most prominent element in our interviews, amounting to a majority of all mentions classified (62 per cent) and mentioned by all interviewees. Subsequent sections discuss these themes in more detail to showcase their differential functional relationship to fraud. 
Table 1: Main themes and sub-themes in interviews

\begin{tabular}{|c|c|c|c|}
\hline Node & Interviews & Numbers of mentions & $\begin{array}{l}\text { Percentage of } \\
\text { mentions* }\end{array}$ \\
\hline Facilitating mechanisms & 35 & 575 & 62 \\
\hline Biraderi networks & 34 & 326 & \\
\hline • general & 16 & 26 & \\
\hline - hierarchy & 14 & 31 & \\
\hline - $\quad$ patriarchy & 28 & 69 & \\
\hline $\begin{array}{l}\text { - patronage and } \\
\text { influence }\end{array}$ & 29 & 126 & \\
\hline - generational change & 23 & 72 & \\
\hline $\begin{array}{l}\text { Political Parties and relations to } \\
\text { Biraderi }\end{array}$ & 33 & 249 & \\
\hline $\begin{array}{ll}\text { - } & \text { biraderi taking } \\
& \text { advantage of parties }\end{array}$ & 19 & 64 & \\
\hline $\begin{array}{l}\text { parties taking } \\
\text { adv.of/tolerating } \\
\text { biraderi }\end{array}$ & 10 & 34 & \\
\hline $\begin{array}{l}\text { parties pushing for } \\
\text { postal vote }\end{array}$ & 14 & 28 & \\
\hline $\begin{array}{l}\text { - parties' campaigning } \\
\text { presence/techniques }\end{array}$ & 27 & 92 & \\
\hline $\begin{array}{l}\text { - } \quad \text { quality of } \\
\text { candidates/councillors }\end{array}$ & 11 & 22 & \\
\hline $\begin{array}{l}\text { - parties' responsibility } \\
\text { to educate }\end{array}$ & 5 & 8 & \\
\hline Opportunities & 27 & 126 & 13 \\
\hline $\begin{array}{l}\text { Intimidation outside polling } \\
\text { stations }\end{array}$ & 8 & 14 & \\
\hline Polling station personation & 12 & 19 & \\
\hline Postal voting & 24 & 63 & \\
\hline Postal voting - grey area & 8 & 13 & \\
\hline Proxy voting & 4 & 4 & \\
\hline Registration & 7 & 13 & \\
\hline Vulnerabilities & 32 & 135 & 14 \\
\hline Language and knowledge & 28 & 62 & \\
\hline Local economic deprivation & 7 & 16 & \\
\hline Political exclusion & 16 & 38 & \\
\hline 'Homeland' political culture & 13 & 19 & \\
\hline Miscellaneous & & 81 & 8 \\
\hline Mosque involvement & 29 & 53 & \\
\hline Source & 17 & 28 & \\
\hline Total & 35 & 917 & \\
\hline
\end{tabular}

*All percentages rounded down and hence do not add up to a 100. 


\section{The risk of electoral fraud}

We found that the three elements of the causal explanation for electoral fraud existed in all the areas, regardless of their 'high risk' and 'low risk' status. Although we do not have equal numbers of interviewees from both types of localities (see Table 2), and the interviews from 'low risk' areas tended to be shorter on average and contain fewer relevant mentions of fraud, the percentages of the different elements in our causal link show that the overall narrative of fraud in both types of place is similar. The interviews in 'high risk' areas yielded more mentions of facilitating mechanisms and opportunities to commit fraud, while those interviewed in 'low risk' areas were more likely to refer to overall vulnerabilities to fraud. However these differences are small: opportunities were mentioned 15 per cent of the time in 'high risk' areas and 10 per cent in 'low risk' areas; facilitating mechanisms amounted to 64 per cent of all mentions in 'high risk' and 60 in 'low risk' areas; and vulnerabilities accounted for 13 per cent of mentions in 'high risk' and 16 per cent in 'low risk' areas. Sadly this points to the fact that most Pakistani and Bangladeshi communities experience some vulnerability to electoral fraud, even if the overall likelihood of fraud remains relatively small. 
Table 2 Main themes and sub-themes in areas of 'high risk' and 'low risk' of electoral fraud

\begin{tabular}{|c|c|c|}
\hline & High risk area (\% mentions) & Low risk area (\%mentions) \\
\hline Facilitating mechanisms & 64 & 60 \\
\hline - $\quad$ Biraderi & 36 & 34 \\
\hline - $\quad$ Parties & 27 & 25 \\
\hline Opportunities & 15 & 10 \\
\hline Vulnerabilities & 13 & 16 \\
\hline Misc. & 7 & 12 \\
\hline Total no. interviews & 19 & 16 \\
\hline Total no. mentions & 621 & 296 \\
\hline
\end{tabular}

\section{Vulnerability to fraud}

Given that vulnerabilities to fraud are a dominant explanation of fraud in the literature, it is unsurprising that most of our interviewees discussed them. Our participants identified four sources of vulnerability: language and knowledge barriers, local economic deprivation (although again, because of lack of variance in our sample we cannot extend this finding to other economically deprived areas), 'homeland' political culture and political exclusion; all well-known from the literature. However, the distribution of these was more surprising. Although local and personal economic deprivation was present, only seven from our 35 interviewees mentioned it. Similarly, the often assumed culprit of the political experience imported from origin countries with less developed democratic practices (Mawrey 2015; Metropolitan Police 
Authority 2006), was present in only 13 interviews, despite prompting for it in our interview schedule. This is particularly notable given the link between corruption and social and cultural norms identified by Fisman and Miguel (2007).

The most prominent vulnerability was a lack of individual resources in the form of language and knowledge barriers, which was mentioned by 28 interviewees and amounted to more than half of all mentions of vulnerabilities to fraud. We found that language and knowledge barriers are especially widespread among more recently arrived immigrants, and particularly affect women. Voters experiencing these barriers receive help from their community and family with the voter registration process and filling out their postal voting statement. This support can be invaluable if carried out properly because it enables people to vote. However, migrants with poor English may also receive 'assistance' when filling out their postal ballot; and some may even be unsure about the purpose of the form they are signing. Voters may fall prey to disingenuous help and pressure to fill out their vote in a certain way. We heard accounts of postal votes being kept from people altogether and filled out by somebody else. Without knowledge of the British political and legal systems and with limited language skills, those seeking help may be unaware that these practices are wrong and be unable to report them if they are aware. Even without this clearly fraudulent behaviour, the informal help with language issues may lead to undue influence and 
patronage politics later. We heard many accounts of community elders serving the communities, especially in the past when the majority of people could not speak English, and effectively earning political capital that was then expected to be repaid by voting for this person.

Another source of vulnerability mentioned prominently by our interviewees was political exclusion suffered by Pakistani and Bangladeshi communities (other literature indicates it is also an issue for other ethnic minority groups, see Durose et al. 2013). Exclusion from the political process could mean that committing electoral fraud is seen as a necessary way to gain political representation. 16 interviewees felt that persistent discrimination and ghettoization of ethnic minority candidates at the stage of selection means that being of Pakistani or Bangladeshi origin is an obstacle in reaching political office. The blame was usually laid equally with the white British voters- thought to be unlikely to vote for an Asian candidate - and the parties. This former perception is empirically accurate, as studies show that Muslim candidates, who in the UK are predominantly of Pakistani and Bangladeshi origin, suffer a penalty from white voters (Fisher et al. 2015).

Local economic deprivation can also represent a lack of collective resources and some interviewees mentioned lack of funds and cuts to funds as an obstacle to establishing 
and supporting community organisations. The dearth of these organisations may lead to a community relying on self-proclaimed leaders and biraderi networks. Although in our interviews individual-level poverty was not explicitly mentioned, we heard of people being offered food, drink, and even money in return for voting (an electoral offence called treating). Given the existing literature suggests that machines buy votes from poorer voters who place higher value on the favours they offer (Stokes, 2005; Nichter, 2008), both local deprivation and individual-level poverty might increase vulnerability to fraud among South Asian communities. Notably, vulnerabilities to fraud constituted a relatively larger proportion of mentions in 'low risk' areas indicating that in these areas vulnerabilities exist and should be treated seriously in any fraud-prevention activities, even if- according to our theoretical frameworkvulnerability is a necessary, but not sufficient cause of electoral fraud. In other words, it may raise the risks, but is unlikely to directly cause fraud (which is why it remains infrequent in the UK). This leads us to the second element in the explanatory chain: opportunities to commit fraud.

\section{Opportunity for electoral fraud}

Even in a context where vulnerability to fraud exists, the actual incidence of electoral fraud can only occur where there is opportunity. Insufficient safeguards to voting are 
where these opportunities arise. This is the best-known area of fraud, particularly with the increasing consensus that postal voting creates a clear opportunity for fraud. Our interviewees generally shared this perception, with 27 mentioning fraud opportunities and the majority of those- 24- engaged directly with issues around postal voting. This is in keeping with statistics showing that the majority of electoral fraud allegations and convictions since the early 2000 s have been related to postal voting (Wilks-Heeg 2008; White 2014). Voting by post does not provide the same level of security as voting in the polling station (see Clark and James 2017). Whilst the home may be private and protected from the outside world, it is not a private place for those residing in it (Birch and Watt 2004). This increases the chance of an elector experiencing undue influence and intimidation in the voting process, preventing them from making an individual choice. It also enables the political brokers- in this case biraderis - to buy votes.

Other, much less mentioned opportunities for fraud included registration fraud, of the type described in Mawrey's ruling (2015), gangs of men outside of the polling stations on Election Day creating an intimidating presence, and personation at the polling station (see Table 1). Personation, while extremely rare, and very unlikely to influence the results of elections, may be more frequent in South Asian communities for two reasons. Firstly, because of a habit of asking people informally to cast a ballot 
(without an official proxy vote) as a matter of convenience without understanding that this is fraudulent. This practice was also observed by Neill (1952) in Northern Irish elections. According to Neill, those voting on behalf of others in this way saw it as a form of 'benign' personation (as opposed to 'malign' personation). Secondly, a lot of individuals are given the same name at birth and informally use a different name: sometimes forgetting which of these names, or in what form, were put on forms. This could enable someone to inadvertently commit personation but it may also be exploited in order to commit 'malign' personation.

In areas designated as 'low risk', there were substantially fewer mentions of opportunities to commit fraud: ten per cent in comparison to 15 per cent in 'high risk' locations (see Table 2). This indicated fewer interviewees directly witnessed or worried about security breaches and chimes in with lack of recent allegations of fraud in these areas.

\section{Facilitating mechanisms}

While the vulnerabilities to fraud create a context in which individuals and groups are able to take advantage of resource-poor voters, and opportunities provide them with a breach in the safety procedures that enable them to do so, these individuals' and 
groups' methods form the third necessary element leading to electoral fraud. This element was the most prominent in the minds of our interviewees, all of them mentioned it, and mentions amounted to 62 per cent of our coded content. Before conducting fieldwork, we expected biraderi networks to provide us with such a micromechanism. However, during the course of the interviews it became clear that what we initially thought would be part of the local context- the campaigning and candidate selection strategies of political parties- is a second important facilitating mechanism. We will discuss each in turn, drawing on the links between them as well.

\section{Biraderi}

More than a third of all of our coded content related to the activities of biraderi networks. Biraderis are hierarchical and patriarchal social structures operating on a system of community loyalties and pressures (Piliavsky 2014). They often provide welfare for their members and in Britain have responded to the needs created by a lack of structural resources as a result of migration. Newcomers may rely on the biraderi for anything from employment and accommodation to help with official forms and processes (Shaw 2000; Akhtar 2013). Biraderis have thus proved an invaluable source of support for disadvantaged communities and are especially 
valuable for newcomers and some women who are otherwise excluded from formal means of education (Shaw 2000). In voting, biraderis have been important in rectifying problems created by language and knowledge barriers and local economic deprivation and have provided a sort of voter education to their members, enabling them to participate in the electoral process. In fact, biraderi influence is probably responsible for the high levels of electoral participation among South Asian communities (Fieldhouse and Cutts 2008). As all new immigrants from Pakistan and Bangladesh can register to vote upon arrival, this role is potentially a strong political force.

Although we intended to prompt for the influence of biraderis, they were offered unprompted as the dominant narrative by almost all of our interviewees. 34 out of our 35 interviewees mentioned biraderis unprompted one or more times (see Table 1). Many noted that they play positive and needed functions, but also acknowledged that they are a mechanism facilitating electoral fraud and there was a general consensus that biraderis play too large a role in elections. Biraderis are usually highly hierarchical and patriarchal structures led by male elders, and they are often semiformalised. 29 interviewees felt that biraderi elders can use their position in the biraderi to unduly influence the votes of biraderi members. Three reasons for this influence were identified. 
Firstly, elders may attempt to influence the votes of biraderi members in order to help a Pakistani or Bangladeshi candidate overcome political exclusion. In exchange, elders often receive benefits if that candidate is elected. Past research has suggested that reliance on biraderi has been a necessary way of overcoming discrimination and disadvantage for access to elected office (Akhtar 2013; Purdam 2001). Among our interviewees all parties were perceived to mount substantial barriers to entry for Asian candidates unless they were receiving support from biraderi elders who would provide a bloc vote and ensure electoral victory. The perception of discrimination both from parties and voters may counter-balance any sense of wrongdoing among those candidates who do not want to rely on biraderi networks to get selected and elected. Our interviewees saw the activities of biraderi networks in the candidate selection process as both a negative phenomenon that prevents some people from becoming political candidates and delivers poor quality candidates, and a necessary means of overcoming discrimination. As one interviewee explained:

On the one hand, they condemn openly, vigorously these grouping based on biraderis and the regions. They condemn that. But on the other hand, without having that, they can't move further...you know... 
they can't progress at all... they can't enter in that field $[\ldots]$ they're having to face this barrier. (Asian activist).

Secondly, as a result of a class-like component, the relationship between biraderis is hierarchical with some biraderi networks considered to be superior to others. This can create rivalry and competition in the electoral process and lead to a risk of electoral fraud as each network competes to get their candidate selected and elected.

Thirdly, biraderi elders take on a political brokerage role between parties and voters where they promise a certain number of votes in exchange for favours. They are 'organisational brokers' (Holland and Palmer-Rubin 2015) who choose which party to support based on the benefits on offer to them and their organisation (their biraderi). Here political parties are in effect engaging in a practice of vote buying where they are offering rewards to political brokers in exchange for a bloc vote. To create this bloc vote, and receive the promised favours, biraderi elders need to call upon members of the biraderi to vote for the preferred candidate. They can abuse their hierarchical position and take advantage of an emphasis on loyalty to family and biraderi. Voting together as a family is emerging as a universal phenomenon from the newer voter literature that shows that families of all backgrounds tend to go to the polling station together (Fieldhouse and Cutts 2008) and influence each other in their 
decision to vote (DeRooij 2014). However, it was widely reported by our interviewees that in Pakistani and Bangladeshi origin communities, family voting is more clearly hierarchical. In part, this is because of the positive functions of biraderi discussed above. In return for welfare and support, it is expected that biraderi members will be loyal to their elders, and this can include voting as instructed. This is essentially a patronage relationship where elders are patrons offering rewards and benefits to their biraderi members in exchange for loyalty.

Their position in the biraderi hierarchy means that women and young people are particularly likely to be victims of this practice. We were told by some of our interviewees that women and young people are encouraged to apply for postal ballots that they never see, or are instructed on how to complete them by an elder. Some interviewees felt that although a lack of safeguards means that it is easier to influence a postal ballot, women and young people will also face pressure when voting at the polling station. Interestingly, this practice of instructing or even voting on behalf of women and young people was seen as a potentially grey area in some of our interviews (including eight interviewees who felt it was a grey area to fill out their postal votes without their involvement). Women and young people were thought to have less interest in and knowledge about politics and so deferring to elders was seen as acceptable. Similarly, deferring to elders on the basis of respect and loyalty was 
seen as something that is fairly earned by biraderi elders through their service to the community and sometimes as something women and young people may be reasonably expected to do. However, if coercion entered such practices, this was then considered a case of clear-cut electoral fraud: i.e. some level of consent was generally expected. A large number (23) of our interviewees noted that this consent is more commonly withdrawn among younger generations, especially those born in the UK, creating a welcome change to the biraderi-style politics.

This patronage relationship also manifests itself in a semi-formalised system of reciprocity. The level of this formalisation varied in our interviews. It ranged from promising votes on the basis of friendship and as a favour, with the strong expectation of reciprocity, to an almost formal arrangement by which the voters who supported a local candidate can call on them in the middle of the night for help, and with little being out of bounds in terms of what can be asked of one's representative. Pakistani and Bangladeshi origin councillors are sometimes providing, in effect, an all hours service covering a wide range of personal and business issues that would not usually fall within the bounds of work for a non-Asian councillor. An activist explained to us:

My home is theoretically open 24/7. I have had people knocking at 11 o'clock at night saying “can you sign my passport for me?” or 6.45 in 
the morning saying "actually I am off to London can you give me a signature please?" And that is just the way it is [...] you just have to accept that. (Asian activist)

The services of the councillor were understood to be exclusively 'earned' by those residents who have cast a vote for this candidate. Voters who supported the opposition had seemingly no claim on the elected councillor's time and help. As a result many of our interviewees explained that the voters wanted the candidates to see their vote so that their claim to the future councillor's services is beyond doubt. As a result, the voters may actually want the candidate to be present in the house whilst they fill out their postal ballot paper. To the same end, voters may bring signed (declarations) but not completed postal ballots to the candidate- often in bulk from their family. A few of our interviewees used the expression 'carrier bags' full of votes when describing someone delivering votes on behalf of a network. One interviewee described a system in which a head of a household split the family's votes between candidates thus making both these candidates in debt to his family and obliged to serve it:

I've equally heard... where political party agents have gone round and said "You've got five votes, can we please have them?" And 
they [say] "Tell [you] what, you can have three and I'm gonna give two to the other one". (Asian activist)

In the 'low risk' areas we heard about biraderi-related mechanisms for committing fraud only slightly less often: 34 per cent of mentions, as opposed to 36 per cent in 'high risk' areas. However, these mechanisms were reported as generally less sinister in 'low risk' localities: loyalty dominated over coercion and 'carrier bags' of votes were not mentioned. While it indicates that networks who perpetrate fraud elsewhere also operate in those areas, it accords with these localities' lack of experience of fraud, with fewer of our interviewees witnessing fraud first hand. It underlines that all three explanatory factors increasing the risk of fraud are probabilistic and not deterministic in nature, and that fraud remains relatively rare in the UK.

\section{Political Parties}

The second facilitating mechanism is the electoral practices of political parties. 33 out of our 35 interviewees mentioned either the informal adoption of biraderi networks within party campaigning strategy- including local candidate selection- or the lack of party activity that facilitates the emergence of biraderi networks as power brokers to fill the political void created by the parties. These practices directly increase the 
power of biraderi networks. With 249 coded mentions implicating the role of the parties as a micro-mechanism explaining how fraud happens, this was the second most common theme in our analysis (see Table 1). Worryingly, this theme was also well represented in our interviews in 'low risk' areas, with only two per cent fewer mentions of it than in 'high risk' areas.

The informal adoption of biraderi networks within party campaigning strategy is a well-known phenomenon and often emerges in the media. Biraderi elders become powerful middle-men between voters and political parties, and biraderi becomes a political machine reminiscent of those observed in developing democracies. According to Garbaye (2005), this adoption of self-identified community leaders as the link between a party and the ethnic minority voters represents a British model of incorporation of ethnic minority voters. While at first this led to positive outcomes for these communities - with increases of participation and representation - this mode of incorporation may have outlived its initial purpose.

One of the reasons why this practice might increase the risk of fraud in areas where the other two causal factors- vulnerability and opportunity- are present, is that when biraderis are adopted into party campaign strategy, voters are defined as a group rather than individuals. Votes belong collectively to the head of the household rather 
than to each individual voter. In the modern understanding of elections a voter is an individual- a notion supported by the 'one person, one vote' principle and safeguarded by the secrecy of the ballot. Electoral fraud of the kind we heard about during our interviews was often breaking these two principles, and many of our interviewees thought that the misunderstanding of these principles needed to be tackled with awareness campaigns and voter education in Pakistani and Bangladeshi origin communities. However, the interviewees indicated that political parties are not only failing to provide this education, they are also perpetuating the notion of a Pakistani and Bangladeshi voter as a group. This might encourage vote buying because votes are seen as belonging to a few individuals and can be traded for rewards.

Secondly, parties' withdrawal from many of the areas studied enabled biraderi networks effectively to take over many of the political roles of the parties, including candidate selection and electioneering. A lack of campaign activity by political parties in ethnic minority communities was highlighted by the 2010 British Election Study and Ethnic Minority British Election Study: $71 \%$ of white British respondents said that they had been contacted by a political party, compared to just $47 \%$ of ethnic minority respondents, even in marginal constituencies (Sobolewska, Fieldhouse and Cutts 2013). Our interviewees also indicated a lack of party activity in some of our localities: 
'I am saying go and talk to people, go to the houses, go and talk to them. Have the decency to knock on someone's door, you never met Asians before. You never in 20 years knocked on Asian doors'. (Asian activist)

19 interviewees described how biraderi networks may fill such a political void, including when candidates assume the party's label not as a means of receiving support- as support springs from the ethnic loyalties and personal vote- but as a signal that they are 'serious' candidates. In one area we heard mentions of the 'Asian Labour party' as a label distinguishing the local activists acting on behalf of the kinship network from the local Labour party, which was absent from this area. This kind of shallow loyalty to any political party has been a recurring theme. In some areas that were contested by more than one party, a competition between two competing kinship networks or ethnic factions representing different parties emerged. Alternatively, younger or disaffected groups of voters aligned themselves with another political party in an open bid to overthrow the dominance of their ethnic kinship structure: 
'when the first Asian candidate stood, everybody supported him thinking 'It's the first Bengali guy, it's the big thing for our community $[\ldots]$. So he stood, he was from Sylhet, so then, the other group said to him, we want someone from our area to stand next time and he said 'NO'. So they joined the Liberal Democrat party and said 'You are not gonna give us a chance, we are gonna make our own party"' (Asian activist)

\section{Conclusion}

This paper argues that a lot of existing explanations for electoral fraud in developing democracies extend to how and why fraud occurs in an advanced democracy, despite the obvious differences between the frequency and overall likelihood of fraud in these two different kinds of systems. We used a case study of Britain, where fraudparticularly among South Asian communities (Mawrey 2015)- has recently been more politically salient, even if it remains infrequent. Using the existing literature and 35 semi-structured elite interviews with political and community activists in areas of 'high' and 'low' risk of fraud, we also formalised a typology of causes of fraud. 
The first type of causes, political and socio-economic vulnerabilities to fraud, create the context in which fraud can be motivated and enabled. Many of these vulnerabilities are particularly wide spread among South Asian, and some other immigrant-origin communities as, in addition to deprivation and political alienation existing among some native British communities, people of immigrant background suffer additional exclusion based on the lack of knowledge and language proficiency, or disadvantages based on ethnicity and race. This may explain why the small risk of fraud is relatively larger among these communities.

The second type of causes, the opportunities to commit fraud, consists of insufficient safeguards to voting, in particular through postal voting on demand. These are the most often discussed in the UK literature, and the vast majority of policy also focuses on this area of fraud prevention. This is predominantly because out of all types of causes discussed here, these generalize most easily to other communities in the UK. As our research suggests, however, these opportunities are not sufficient for fraud to take place, as the context of vulnerability and facilitating mechanisms are characteristic of places where fraud takes place: communities high in political resources, with a high presence of party campaigning will have very little incentive to exploit opportunities for fraud. As a result, some of the existing or proposed policy reforms in this area can be disproportional and selective. 
In a recent report, 50 reforms to electoral law have been proposed (Pickles 2016), focussing particularly on the types of risk that remain extremely low, even in vulnerable areas, such as personation (see Clark and James 2017), by proposing ID requirements at polling stations, which is known to increase the difficulty of voting and therefore repress turnout. Although proposals to tackle the much more significant risk surrounding postal voting, such as the ban on handling postal votes by party activists, the limit on the number of postal votes that can be handed in at the polling station, and the need to renew the application to vote by post periodically are generally well founded given the evidence presented here and elsewhere (Sobolewska et al. 2015). However, to be truly effective, policy must not only be proportional to the risk, but also move away from tackling opportunities alone and in isolation from other types of causes described here, particularly the vulnerabilities (perhaps through the means of civic education). Especially, the dangers of making voting difficult- for example through ID requirements, particularly when dealing with communities already suffering from political exclusion, might be counter-productive by increasing contextual vulnerabilities and the effectiveness of facilitating mechanisms.

The final type of causes described here were facilitating mechanisms, operating through biraderi networks and political parties. While our interviews were carried out 
at the ward level after local elections and we interviewed local activists, we believe these mechanisms can operate at other elections too. Biraderi networks, although they may be less influential on a larger geographical scale, are likely to control the South Asian voters' vote choices. Political parties might be more active in national than in local elections, although the large and growing number of safe seats in the UK means that it will not be so in many areas of the country. Also, the existing data indicate that even in national elections, ethnic minority voters are less likely than White British voters to be contacted by political parties (Sobolewska, Fieldhouse and Cutts 2013). This suggests that, for ethnic minority communities at least, the campaign activities of political parties will continue to be a facilitating mechanism for electoral fraud regardless of the type of election.

\section{References:}

Akhtar, P. (2013) British Muslim Politics: Examining Pakistani Biraderi Networks. Basingstoke: Palgrave Macmillan.

Alvarez, R. M. and Hall, T. (2008) Electronic Elections: The Perils and Promises of Digital Democracy. Princeton: Princeton University Press. 
Alvarez, R. M., Hall, T. and Hyde, S. (2008) Introduction. In: Alvarez, M., Hall, T. and Hyde, S. (eds) Election Fraud: Detecting and Deterring Electoral Manipulation. Washington D.C.: The Brookings Institute: 1-18.

Beber, B. and Scacco, A. (2012) What the Numbers Say: A Digit-Based Test for Election Fraud. Political Analysis 20 (2): 211-234.

Beaulieu, E. (2016) Electronic Voting and Perceptions of Electoral Fraud and Fairness. Journal of Experimental Political Science 3 (1): 18-31.

Birch, S. and Watt, B. (2004) Remote Electronic Voting: Free, Fair and Secret?. The Political Quarterly 75 (1): 60-72.

Cabinet Office (2016) A Democracy that Works for Everyone: A Clear and Secure Democracy: Government responses to Sir Eric Pickles' review of electoral fraud. London: The Cabinet Office.

Charsley, K., Van, H.N., Benson, M. \& Storer-Church, B. (2012) Marriage-related migration to the UK. International Migration Review, 46 (4): 861-890.

Clark A. (2015) Public Administration and the Integrity of the Electoral Process in British Elections. Public Administration 93 (1), 86-102.

Clark A. (2016) Identifying the Determinants of Electoral Integrity and Administration in Advanced Democracies: The Case of Britain. European Political Science Review, advance e-publication ahead of print. 
Clark, A. and James T.S. (2017) Poll Workers. In: Norris, P. and Nai, A. (eds) Election Watchdogs: Transparency, Accountability and Integrity. Oxford: Oxford University Press.

Council of Europe Parliamentary Assembly (2007), Application to initiate a monitoring procedure to investigate electoral fraud in the United Kingdom. AS/Mon 38.

DeRooij, E. (2014) Shamed into voting: how our nearest and dearest motivate us to turn out. In: Cowley, P. and Ford, R. (eds) Sex Lies and the Ballot Box. London: Biteback Publishing: 51-54.

Durose, C., Richardson, L., Combs, R., Eason, C. and Gains, F. (2013) "Acceptable difference": diversity, representation and careerism in UK politics. Parliamentary Affairs 66 (2): 246-267.

Electoral Commission, Who is eligible to vote at a UK general election?. Available at: http://www.electoralcommission.org.uk/faq/voting-andregistration/who-is-eligible-to-vote-at-a-uk-general-election (Last accessed: 11/08/2016).

Electoral Commission (2013) Electoral Fraud in the UK: Evidence and issues paper. London: The Electoral Commission. 
Electoral Commission (2014) Electoral Fraud in the UK: Final Report and Recommendations. London: The Electoral Commission.

Fieldhouse, E. and Cutts, D. (2008) Mobilisation or Marginalisation? Neighbourhood Effects on Muslim Electoral Registration in Britain in 2001. Political Studies 56 (2): 333-354.

Fisher, S., Heath A., Sanders, D., and Sobolewska, M. (2015) Candidate Ethnicity and Vote Choice in Britain. British Journal of Political Science 45 (4): 883-905.

Fisman R. and Miguel E. (2007) Corruption, Norms, and Legal Enforcement: Evidence from Diplomatic Parking Tickets. Journal of Political Economy 115 (6): 1020-1048.

Fukumoto, K. and Horiuchi, Y. (2011) Making Outsiders' Votes Count: Detecting Electoral Fraud Through a Natural Experiment. American Political Science Review 105 (3): 586-603.

Gans-Morse, J., Mazzuca S. and Nichter, S. (2014), Varieties of Clientelism: Machine Politics during Elections. American Journal of Political Science 58 (2): 415-432.

Garbaye, R. (2005) Getting into Local Power: The Politics of Ethnic Minorities in British and French Cities. Oxford: Blackwell. 
Guest, G., MacQueen K.M. and Namey E.E. (2012) Applied Thematic Analysis.California: Sage.

Holland, A. C. and Palmer-Rubin, B. (2015) Beyond the Machine: Clientelist Brokers and Interest Organizations in Latin America. Comparative Political Studies 48 (9): 1186-1223.

Hyde, S. (2008) How International Election Observers Detect and Deter Fraud. In: Alvarez, M., Hall, T. and Hyde, S. (eds) Election Fraud: Detecting and Deterring Electoral Manipulation. Washinton D.C.: The Brookings Institute: 201-215.

James, T. S. (2011) Fewer Costs More Votes? United Kingdom Innovations in Election Administration 2000-2007 and the Effect on Voter Turnout. Election Law Journal 10 (1): 37-52.

James, T.S. (2013) 'Fixing failures of UK electoral management'. Electoral Studies 32 (4): 597-608.

Jensen, P. S. and Justesen, M. K. (2014) Poverty and vote buying: Survey-based evidence from Africa. Electoral Studies 33: 220-232.

Lehoucq, F. (2003) Electoral Fraud: Causes, Types and Consequences. Annual Review of Political Science 6: 233-256.

Lemann, L. and Bochsler, D. (2014) A systematic approach to study electoral fraud. Electoral Studies 35: 33-47. 
Mawrey R (2015) Judgement in the High Court of Justice M/350/14 Queen's Bench Division In the Matter of the Representation of the People Act 1983 and in the Matter of a Mayoral Election for the London Borough of Tower Hamlets Held on 22 May 2014.

Mebane, W. (2008), 'Election Forensics: The Second Digit Benford's Law Test and Recent American Presidential Elections'. In: Alvarez, M., Hall, T. and Hyde, S. (eds) Election Fraud: Detecting and Deterring Electoral Manipulation. Washinton D.C.: The Brookings Institute: 162-181.

Mebane, W. (2006), Election Forensics: Vote counts and Benford's law. Paper prepared for the 2006 Summer Meeting of the Political Methodology Society, UC-Davis, Davis, CA, July 20-22.

Metropolitan Police Authority (2006) Electoral offences in London following the local elections of May 2006, report by Assistant Commissioner Specialist Operations. London: MPA.

http://policeauthority.org/Metropolitan/committees/mpa/2006/061026/14/index.ht $\mathrm{ml}$ (last accessed 28.01.2016)

Minnite L.C. (2010) The Myth of Voter Fraud. Ithaka: Cornell University Press.

Neill, D. G. (1952) The Election in Northern Ireland. In: D. Butler, The British General Election of 1951. London, Macmillan: 220-235. 
Nichter, S. (2008). Vote Buying or Turnout Buying? Machine Politics and the Secret Ballot. American Political Science Review 102 (1): 19-31.

Norris, P. (2015) Why Elections Fail?. Cambridge: Cambridge University Press.

Norris, P., Frank R. W. \& Martínez i Coma, F. (eds.) (2014) Advancing Electoral Integrity. New York: Oxford University Press.

Peace, T. and Akhtar, P. (2015) Biraderi, Bloc Votes and Bradford: Investigating the Respect Party's Campaign Strategy. The British Journal of Politics and International Relations 17 (2): 224-243.

Pickles, E. (2016) Securing the ballot. London: The Cabinet Office.

Pilivasky, A. (ed.) (2014) Patronage as Politics in South Asia. Cambridge: Cambridge University Press.

Purdam, K. (2001) Democracy in Practice: Muslims and the Labour Party at the Local Level. Politics 21 (3): 147-157.

Saglie, J. and Segaard, S. B. (2016) Internet voting and the secret ballot in Norway: principles and popular understandings. Journal of Elections, Public Opinion and Parties 26 (2): 155-169.

Shaw, A. (2000) Kinship and Continuity: Pakistani Families in Britain. London: Routledge. 
Stewart, J. (2006) A Banana Republic? The Investigation into Electoral Fraud by the Birmingham Election Court. Parliamentary Affairs 59 (4): 654-667.

Stokes, S., Dunning, T., Nareno, M., Brusco, V. (2013) Brokers Voters and Clientelism: The Puzzle of Distributive Politics. Cambridge: Cambridge University Press.

Stokes, S. (2005) Perverse Accountability: A Formal Model of Machine Politics with Evidence from Argentina. American Political Science Review 99 (3): 315325.

Sobolewska, M., Fieldhouse, E., and Cutts, D., (2013) Who takes the black vote for granted? Electoral campaign and ethnic targeting: the case of Britain. Parliamentary Affairs 66 (2): 329-44.

Sobolewska, M. and Heath, A. (2014) Voter engagement in the UK: the case of ethnic minorities. Written evidence submitted to Political and Constitutional Reform Committee (House of Commons). Available at:

http://data.parliament.uk/writtenevidence/committeeevidence.svc/evidencedocum ent/political-and-constitutional-reform-committee/voter-engagement-in-the$\mathrm{uk} / \mathrm{written} / 6513 . \mathrm{html}$

Sobolewska, M., Wilks-Heeg, S., Hill, E., Borkowska, M. (2015) Understanding electoral fraud vulnerability in Pakistani and Bangladeshi origin communities in England. A view of local activists. Available at: 
https://www.electoralcommission.org.uk/_data/assets/pdf_file/0006/181257/Und erstanding-Electoral-Fraud-Jan-2015.pdf

Thrasher, M., Borisyuk, G., Rallings, C. and Shears, M. (2013) BAME Candidates in Local Elections in Britain. Parliamentary Affairs 66 (2): 286-304.

Weingrod, A. (1968) Patrons, Patronage, and Political Parties, Comparative Studies in Society and History 10 (4): 377-400.

White, I. (2014) Electoral offences since 2010, House of Commons Library, Standard Note: SN/PC/06255.

Wilks-Heeg, S. (2008) Purity of Elections in the UK: Causes for Concern. York: Joseph Rowntree Reform Trust.

Wilks-Heeg, S. (2009) Treating voters as an afterthought? The legacies of a decade of electoral modernisation in the United Kingdom. Political Quarterly 80 (1): 101-110.

Ziblatt D. (2009). Shaping Democratic Practice and the Causes of Electoral Fraud: The Case of Nineteenth-Century Germany. American Political Science Review, 103 (1): 1-21. 


\section{Address for correspondence}

Eleanor Hill, Department of Politics, University of Manchester, $4^{\text {th }}$ Floor Arthur Lewis Building, Oxford Road, Manchester, M13 9PL. E-mail:

eleanor.hill@manchester.ac.uk.

\section{NOTES}

i The Electoral Commission initially identified 16 such local authority areas in January 2014, with two additions in late 2014 and 2016. The local authority without a sizeable Pakistani or Bangladeshi population was added in 2016, after our fieldwork.

ii All of Electoral Commissions' 'high risk' locations were in England, despite the fact that their analysis did cover the entire UK.

iii Interviews were then transcribed and anonymised prior to analysis, which was conducted using thematic analysis approach (Guest, MacQueen and Namey, 2012) and QSR NVivo 10 software. The rate of inter-coder agreement calculated on a sample of interviews was between 100-91 per cent for most themes and sub-themes. Three sub-themes were below 90 per cent of inter-coder agreement at 88,86 and 83 per cent- this was deemed acceptable. 